〔日農医誌 65巻 5 号 1019 1022頁 2017. 1〕

\title{
症例報告：
}

\section{島根県雲南市における日本紅斑熱の初報告と その広がりに関する考察}

太田龍 一*,2* ·森 脇 義 弘 $3^{*} \cdot 大$ 谷 順 ${ }^{3 *} \cdot$ 服 部 修 三 ${ }^{2 *}$

島根県雲南市で発生した日本紅斑熱の症例を経験した。症例は77歳女性で, 全身倦急感 を主訴に受診した。当初, 発熱と皮疹, ダニの刺し口の痂皮からツツガムシ病と診断し加 療していたが, 痂皮の PCR 法で Rickettsia japonica が陽性となり, 日本紅斑熱の確定診 断となった。雲南市における日本紅斑熱の初めての症例である。島根県内では北部から南 部への日本紅斑熱罹患者の拡大が観察されているが, これは媒介動物であるイノシシ移動 とともに起こるRickettsia japonica をもったマダニの生息域の拡大によるものと考えら れ，今後イノシシの生態調査が望まれる。

(1)日本紅斑熱 (2)島根県 (3)雲南市 (4)媒介動物 (5)インシ

\section{緒言}

日本紅斑熱は, 紅斑熱群リケッチアの 1 つで ある Rickettsia japonicaによる感染症で, マ ダニを介して感染し, 全例報告が義務付けられ ている 4 類感染症に分類されている。症状は多 彩で，発熱，紅斑，刺し口の痂皮化が有名であ る。1984年に日本で初例が報告されたが1), そ の後, 報告症例数は年々増加しており, 太平洋 岸を中心として, 北は青森県, 南は沖縄県で症 例が確認されているなど全国に広がってい る2)。重症化の可能性があり，早期発見，早期 治療が重要である3)。島根県では, 1987年大社 町で日本海側では初めての症例として第 1 報が なされ(4), その後, 島根半島を中心として, 松 江市, 出雲市で数例の症例が毎年報告されてい る。一方, ツッガムシ病に関しては, 島根県保 健環境科学研究所の田原らの報告では, 島根県

* T699-1221 島根県雲南市大東町飯田96-1

雲南市立病院地域ケア科

$2 *$ 同 内科

$3 *$ 同 地域総合診療科

（受付：2016年 8 月 8 日)
南部に位置する雲南市で頻度が高い5)。しかし 日本紅斑熱の報告はなかった。マダニ刺傷の広 がりに関して, マダニを運ぶ媒介動物の存在が 指摘されており, マダニを運ぶ中媒介動物とし て, 野鼠, 野鬼, 鹿, 犬, 猫, イノシシなどの 可能性は指摘されている れていない。

今回, 雲南市からの日本紅斑熱症例の初例を 経験したので報告する。また島根県での日本紅 斑熱の広がりに関してイノシシの生息域の広が りを中心に考察する。

\section{症例}

\section{7歳女性}

主訴：全身倦总感

現病歴：患者は雲南市在住で，既往にアルツ ハイマー型認知症があった。来院 4 日前に自宅 の前で, 草刈りをしていたのを同居の長男の義 娘が目撃していた。来院当日の朝から, 食欲が 低下し, 夕方になっても元気が無く食事を摂ら ないため, 2016年 4 月, 当院へ救急搬送となっ た。来院時，バイタルサインは血圧150／ $78 \mathrm{mmHg}$, 脈拍数78回/分, 呼吸数 18 回 / 分, 
体温39.1度， $\mathrm{SpO} 2$ 96\%（室内気）と発熱と比 較的徐脈を認めており，全身に広がる紅斑を認 めた。また右側腹部に $2 \mathrm{~mm}$ 大の紅斑を伴う湻 皮（図 1 ）が観察され，それ以外に身体所見上 の異常はなかった。血液検查所見はCRPが $7.2 \mathrm{mg} / \mathrm{dL}$ と上昇している以外に白血球増多, 肝機能異常, 凝固異常, LDH 上昇, 尿沈渣異 常はなかった。ツツガムシ病と診断し, 痂皮を 剥離し, ツッガムシ /リケッチア PCR 法に出 した後，ミノサイクリン $200 \mathrm{mg} /$ 日を点滴静注 で使用した。抗生剂投与後 2 日で皮疹は軽快

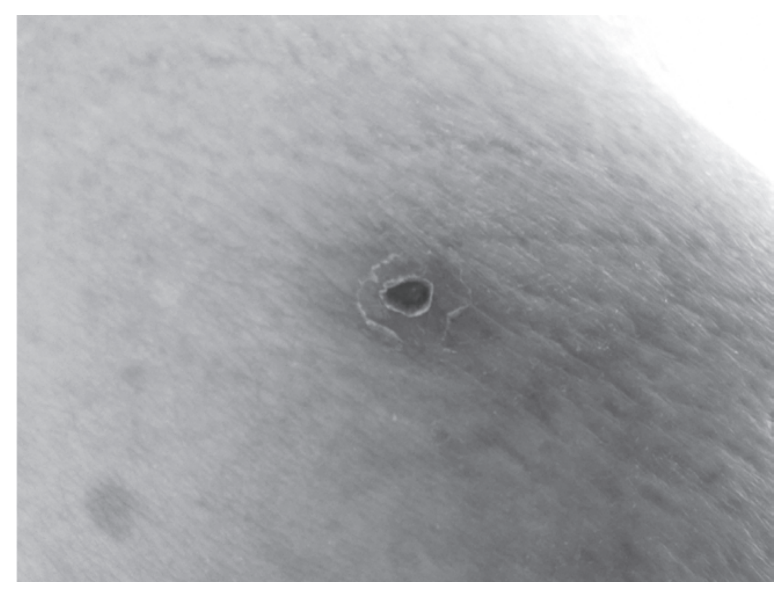

図 1. 右側腹部のマダニの刺し傷
し，5日後解熱した。同時期に，Rickettsia japonica 遺伝子が PCR 法で陽性となり, 血清 の抗体価も日本紅斑熱に対する IgM が320倍, IgG が160倍と上昇を認めた。以上より, 日本 紅斑熱と診断を修正し, 抗菌薬は合計 7 日間使 用し，経過良好で退院した。

\section{考察}

今回の症例は，雲南市での日本紅斑熱の第 1 報であり，島根県内での Rickettsia japonica を持ったマダニの生息域が南下している可能性 を示唆している。

これまでの日本紅斑熱の分布は, ツッガムシ 病の分布とは対称的なものとなっていた（図 2)。日本紅斑熱は県の北側に分布し, 一方, ツツガムシ病は県の南部を中心として広がって 扣り，雲南市がもっとも発生が多い状態であっ た。今回の雲南市での報告によって, Rickettsia japonica をもつマダニが県の南部に広がっ ていることを示唆された。Rickettsia japonica を持ったマダニの生息域の広がりに関しては, 媒介動物の存在が大きな役割を持っていると考 えられる。保科ら の) の報告によると, 島根県内の 家畜を含めた野生動物の Rickettsia japonica

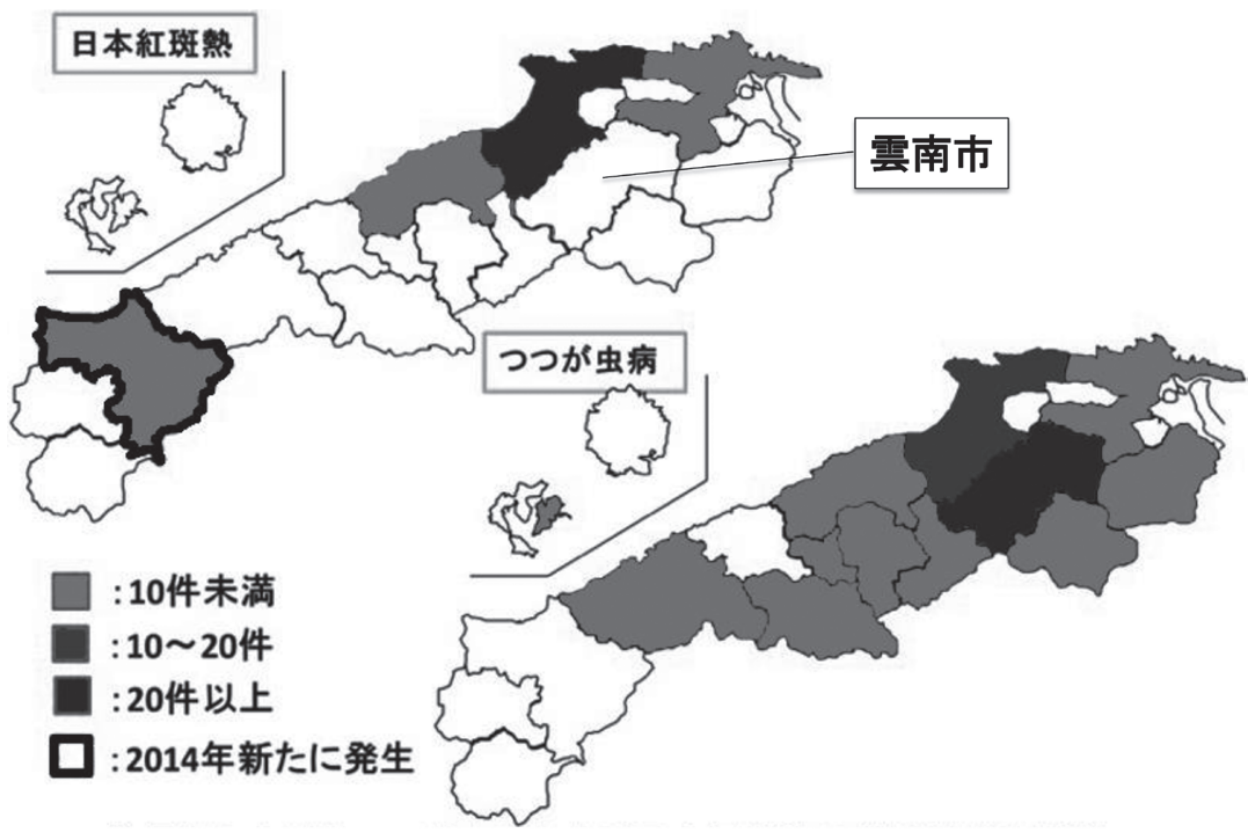

図 2. 島根県に扔けるつつが虫病㧍よび日本紅斑熱の地域的発生状況 （1999～2014年） 
の抗体価を調べたところ，イヌ，ウシ，鹿，ネ ズミで $10 \%$ 以上となっていることが指摘されて

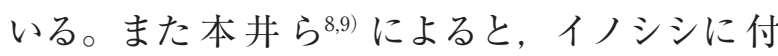
着するマダニの数が野生動物の中でもっとも多 く，イノシシ自体は島根県全体に生息していた が，2004年を境に島根半島周囲の県北部に生息 していたイノシシが島根県全体へ再分布し，そ れによって島根県北部のマダニがそれ以外の地 域に生息範囲を広げていることを示唆してい る。竹下ら ${ }^{10)} も$ 亿ノジの生息地が広がって いることを示しており，Rickettsia japonicaを 持ったマダニの生息域の拡大を説明できる動物 の 1 つしてイノシシの存在が大きなものと なっている可能性が高いと考えられた。今後, 島根県南部の地域におけるイノシシの Rickettsia japonica の抗体価を調べることによって， Rickettsia japonica をもったマダニの広がりを 知ることができるであろう。そして，島根県南 部での発生が予想される日本紅斑熱患者の早期 診断，早期治療へつながると考えられた。

今回の雲南市での日本紅斑熱の第 1 報から, 今後の島根県全体での流行地域拡大へ注意を向 けるべきであると思われた。そして，ベクター である可能性の高いイノシシの生息分布やその 拡散抗体価の調査も望まれる。

\section{結論}

今回，島根県雲南市からの日本紅斑熱の第 1 報を行なった。今後の日本紅斑熱の感染拡大に 注意しながら，早期診断，早期治療を心がける べきであると思われた。

\section{謝 辞}

今回の論文発表に関して, 島根県内のツツガムシ病
〈日本紅斑熱の情報提供いただいた島根県保健環境科 学研究所の三田哲朗氏と藤澤直輝氏, 論文発表にあ たって助言いただいた沖縄県立宮古病院の島袋彰氏, 雲南市立病院皮膚科の大藤聡氏に感謝申し上げます。

\section{著者の COI 開示}

本論文発表内容に関連して特に申告なし。

\section{文献}

1 ）馬原文彦. 日本紅斑熱の発見と臨床的疫学研究. モダンメデイア $2007 ; 54: 32-41$.

2 ) 安藤秀二, 藤田博巳. 国内における紅斑熱群り ケッチア症を媒介するマダニ類と病原体との多様 な関係. Med. Entomol. Zool. 2013；64：5一7.

3 ）兒玉和也, 野口寿行, 近平佳美. 急性呼吸不全を 合併した日本紅斑熱の 1 例。感染症学雑誌 $2000 ; 74: 162-165$.

4 ）岡 暢之, 加藤 讓, 出來尾哲, 他. 山陰地方で 初めて発見された紅斑熱リケッチアの 1 例。感染 症学雑誌 $1990 ； 64: 136-142$.

5 ) 田原研司, 川端寛樹, 安藤秀二, 他. 島根県にお けるつつが虫病の疫学的検討. 日獣学誌 2012 ; $65: 535$ - 541 .

6 ）中尾昌弘, 西村謙一, 岡沢孝雄, 他. 佐賀県の野 鼠寄生ツツガムシと野鼠ならびに住民のつつが虫 病抗体保有率. Med. Entomol. Zool. 1988；39： 155 - 157 .

7 ）保科 健, 糸川浩司, 板垣朝夫, 他. 島根県にお ける紅斑熱群リケッチアに対する各種動物の抗体 保有状況. 感染症学雑誌 $1995 ； 69: 524-531$.

8 ) 本井祐太, 鈴木正嗣, 安藤秀二, 他. 島根半島部 のイノシシ再分布による紅斑熱群リケッチアへの 影響. 第153回日本獣医学会学術集会講演要旨集 $2012 ; 153: 248$.

9 ) 本井祐太. 野生動物の生息状況との関連性に着目 した紅斑熱群リケッチア症の疫学的評価。岐皁大 学獣医学科博士論文, 2012 .

10）竹下幸広，菅野泰広，金森弘樹，他. 島根県に招 けるイノシシの生息害態調査（III）。島根中山間 七研報 $2013 ； 9$ ：31—42. 


\title{
First Case of Japanese Spotted Fever in Unnan City, Shimane Prefecture: How the Disease Spread Here
}

\author{
Ryuichi OHTA*,2*, Yoshihiro MORIWAKI ${ }^{3 *}$, \\ Jun OTANI ${ }^{3 *}$ and Shuzo HATTORI*,2*
}

We encountered a case of Japanese spotted fever in Unnan City, Shimane Prefecture. A 77-year-old woman visited our hospital complaining of fatigue. Initially, we diagnosed tsutsugamushi disease based on the constellation of presenting symptoms and clinical signs including fever, systemic erythema, and an eschar. However, the eschar was submitted for polymerase chain reaction analysis and was found to be positive for Rickettsia japonica. The final diagnosis was Japanese spotted fever. To the best of our knowledge, this is the first report of Japanese spotted fever in Unnan City, and there is a possibility that the condition has spread not only in the north of the prefecture but also in the south. This may be due to the widening habitat of ticks harboring R. japonica. Interestingly, the wild boar, a suspected vector, has expanded its habitat to the south of the prefecture. Research on the ecology of the wild boar is warranted.

Depts. of ${ }^{*}$ Community Care, ${ }^{2 *}$ Internal Medicin, and ${ }^{3 *}$ General Medicine, Unnan City Hospital, Shimane, Japan 